\title{
The Role of Human Capital in Ensuring the Digital Transformation of Russian Companies
}

\author{
Alina Veshkurova ${ }^{1}{ }^{*}$ Nataliya Kopylova ${ }^{2}$, Tatiana Aleksashina ${ }^{3}$, Ekaterina
}

Alyamkina $^{3}$

\author{
${ }^{1}$ Russian University of Transport (RUT (MIIT), Moscow, Russia \\ ${ }^{2}$ Plekhanov Russian University of Economics, Moscow, Russia \\ ${ }^{3}$ Financial University, Moscow, Russia \\ *Email: veshenka@bk.ru
}

\begin{abstract}
The article examines the experience of state corporations and companies with state participation in the implementation of digital transformation programs since, historically, they accumulate best practices. The authors show the paramount importance of corporate human capital when launching digital projects. The factors contributing to and hindering the fuller use of human capital in the digitalisation of companies are identified, and the main indicators of the digital transformation of companies are proposed. It is concluded that Russian companies consider more efficient use of technologies, such as data-based management and customer experience management, as a priority of the digital transformation strategy. While it is evident that accumulated human capital plays a significant role in the digitalisation of business processes. The main areas that contribute to the company's innovation potential and long-term competitiveness are creating its new products $(\mathrm{R} \& \mathrm{D})$ and the development of human capital and competencies (digital culture).
\end{abstract}

Keywords: Digitalisation, Industry, Human capital, Digitalisation processes, Digital economy.

\section{INTRODUCTION}

Digital transformation is the introduction of modern technologies into companies' business processes, which implies replacing equipment, software and a change in approaches to organisational management.

Ensuring the sustainable development of the Russian economy is inextricably linked with the effective use of human capital and the development of its innovative potential.

Special attention is paid to the digital transformation of state corporations (SC), which have historically accumulated advanced experience and production potential of economic sectors in the Russian Federation.

Despite significant differences in approaches to assessing the share of the public sector in the Russian economy, all researchers note its significant size [1]. According to the FAS of Russia in 2014, its share was
$70 \%$. RANEPA experts estimate the state presence in the economy in 2016 at $46 \%$ (40\% in 2006), and the International Financial Fund - 33\%.

On April 19, 2021, the Ministry of Finance of the Russian Federation announced the approval by the Government of directives on the digital transformation of state-owned companies. It is planned that by 2024 , all companies with a $50 \%$ state participation in them will join the implementation of the directives [2].

At the moment, companies with state participation have created the best conditions for accumulating and developing human capital, which is the conductor of digital transformation. Thus, these companies can become a kind of testing ground for introducing innovative management and production technologies to extend the proven practices and approaches to commercial organisations, government agencies, etc. 
The study aims to identify the role of corporate human capital in implementing digital transformation programs.

In the course of the study, the following tasks were set:

- identify the main components of human capital involved in the digitalisation of the company's business processes

- to identify the factors contributing to and hindering the fuller use of human capital in the digitalisation of companies;

- to propose the main indicators of digital transformation of companies.

Integrating digital technologies into business processes is necessary for the survival and ensuring the competitive advantages of modern organisations [3].

Organisations "compete through people", emphasising that success increasingly depends on human capital (considered as the economic value of knowledge workers, their abilities), as well as the ability of an organisation to manage talents [4]. As a result, human resource management becomes more diverse and peopleoriented [5].

In the digital economy, the competitiveness of a country is determined primarily by accumulated and developed human capital, which has a variety of network and digital competencies at various levels: at the global, at the state level (e-government), at the corporate (private companies) and the individual social (social networks) [6].

The term "human capital" first appeared in the works of economist Theodor Schultz, who defined it as valuable qualities acquired by a person that can be enhanced by appropriate investments [7].

At the moment, human capital is interpreted more broadly and includes a wide range of personal qualities, value orientations that can have an indirect impact on the results of productive activity [8].

During the country's transition to the innovative (digital) way of economic development, one of the basic factors of the new innovative economic model will be human capital [9]. Competencies such as the ability to work with information, critical thinking, analytical skills are becoming more and more in demand.

\section{RESEARCH METHODOLOGY}

The authors are based on general methods of scientific research. The method of system analysis made it possible to identify the impact of human capital on the processes of digital transformation of state corporations and companies; the classification method revealed the main innovative components of human capital, statistical methods made it possible to assess the relationship between accumulated human capital and the implementation of the digital transformation strategy.

\section{RESEARCH RESULTS}

At the moment, many indices are used to assess the digital transformation of a business. In our opinion, the Euler Hermes Enabling Digitalisation (EDI) index is of interest, which measures the ability and flexibility of countries to promote the digital transformation of the economy.

EDI consists of 5 components: legislative regulation, knowledge, communications, infrastructure and the number of Internet users

In 2019, the USA, Germany and Denmark were among the top three in terms of the value of this index. Thanks to the best-in-class knowledge ecosystem, the size of a competitive market and favourable regulation, the USA took first place in the ranking. Germany retained its second place with the best knowledge ecosystem (linked to the USA) and infrastructure for trade [10].

According to this index, Russia is not among the top ten and received only 37 points out of 100, despite the "friendly" legislation, which is estimated at 87 points. The development of infrastructure and the quality of communications received low scores in the assessment.

But despite the low indicators relative to the global environment, the Russian SC still has some positive results in digitalisation. Thus, in 2018 Rosatom developed a Unified Digital Strategy until 2030. This document defines five main areas: ensuring internal digitalisation, developing digital products, promoting the digitalisation of Russia, carrying out organisational changes and developing digital culture.

Russian Railways has also developed a Digital Transformation Strategy until 2025, which involves developing digital services, the transformation of culture and business processes, a list of digital projects, the development of human resources, investments in digital platforms infrastructure, etc.

In 2019, the implementation of one of the most extensive digitalisation programs on a federal scale began - in PJSC ROSSETI according to the Digital Transformation Program 2030. The goal of digital transformation is to change the logic of processes and the company's transition to risk-based management based on the introduction of digital technologies and big data analysis [11]

According to a survey conducted by Hanover Research commissioned by the provider of corporate cloud services AHEAD, six factors influence the success of a company's digital transformation [12]: 
1) Purposeful leadership. Someone from the company's top management should lead the digital transformation process.

2) Complexity. The project's success is higher if the digital transformation affects many business processes and will not occur in the form of individual initiatives.

3) Availability of a digital roadmap. Careful planning and strategy ensure that projects are completed on time.

4) Consistency of infrastructure and applications. Enterprises that use the DevOps development methodology in their practice have a higher chance of successfully implementing the digital initiative (by 43\%) than those that do not use it.

5) Platform thinking. Enterprises that link the digitalisation process with the IT infrastructure significantly increase their chances of project success.

6) Intelligence of operations. Companies that monitor the quality of IT work in real-time and quickly eliminate problems, thereby breaking away from short-sighted competitors by $24 \%$.

Accepting and agreeing with the factors identified in the survey that determine the success of corporate digital transformation, we note that the transformation process involves the transition of the company to a new state of constant change, affects the interests of all employees, since it violates established orders, undermines established relationships. Therefore, it is necessary to retrain personnel and involve them in implementing the strategy, maintaining the required level of motivation to implement changes.

Thus, to the factors mentioned above of the success of digital transformation, it is necessary to add the presence of such competence in the manager as "the ability to motivate subordinates to change", as well as the presence of all participants in the changes of the necessary digital competencies and skills. The level of development of digital competencies becomes the most important qualitative characteristic of human capital, on the one hand, and the key to the company's successful digital transformation, on the other.

Digital competencies were formed at the junction of hard and soft skills because, on the one hand, they are specific for a certain type of activity, and on the other hand, they imply a certain level of digital skills of a modern person living in an electronic society [13].

Examples of digital skills: accuracy and fluency of entering information electronically on digital devices; manipulation of source data and translation of information into a form that is easily perceived by the target audience; correct citation and knowledge of the basic concepts of copyright, etc.

An equally important component of human capital is employee motivation management as organisational capital. Studies have shown that employee motivation to learn digital skills depends on [14]:

1) age. The older a person is, the lower their motivation to learn new knowledge;

2) the education level. People with a higher level of education have a stronger motivation to develop digital competencies;

3) past learning experience. If a person has once had a negative experience of learning something, he is much less likely to try again.

4) ideas about the complexity of teaching information and communication technologies.

One of the ways to increase motivation for learning is the formation of digital culture in the organisation.

Digital culture is a set of principles and values in corporate culture that characterise the use of information and communication digital technologies for interaction with society and solving problems in professional activities.

The creation of organisational culture is the foundation of future success due to the implementation of digital transformations and from the point of view of models for assessing the company's digital maturity. Thus, the analysis of such models determines the following criteria to evaluate the digital maturity of companies: strategy and business model, customer experience, organisational culture and personnel, operational processes and information technology [15].

According to the estimates of leading consulting companies, the main obstacles to digital transformation are not so much financial or technological problems but rather a mismatch of organisational culture and a shortage of qualified personnel. Obviously, the development of a digital economy is associated with challenges that cause the inevitability of the transformation of the education sector, the formation of new methods and tools of educational activity [16]. However, studies indicate that the proportion of workers' education who are able to use information and communication technologies in their profession intensively is not high enough [17].

Russian realities correspond to global trends. Thus, the KMDA study "Digital Transformation in Russia" named "insufficient competencies and knowledge" as the main obstacle to the digital transformation of Russian companies (Fig.1).

The respondents noted the lack of qualified personnel and the fear of change. This is interconnected with another parameter - the lack of a strategy because ignorance and misunderstanding of the necessary actions can cause fear of change and generate internal resistance to change. Fundamentally, both in 2018 and 2020, the factors of digital culture and competencies outweigh the 
lack of funding and the risks of obtaining a low return on investment.

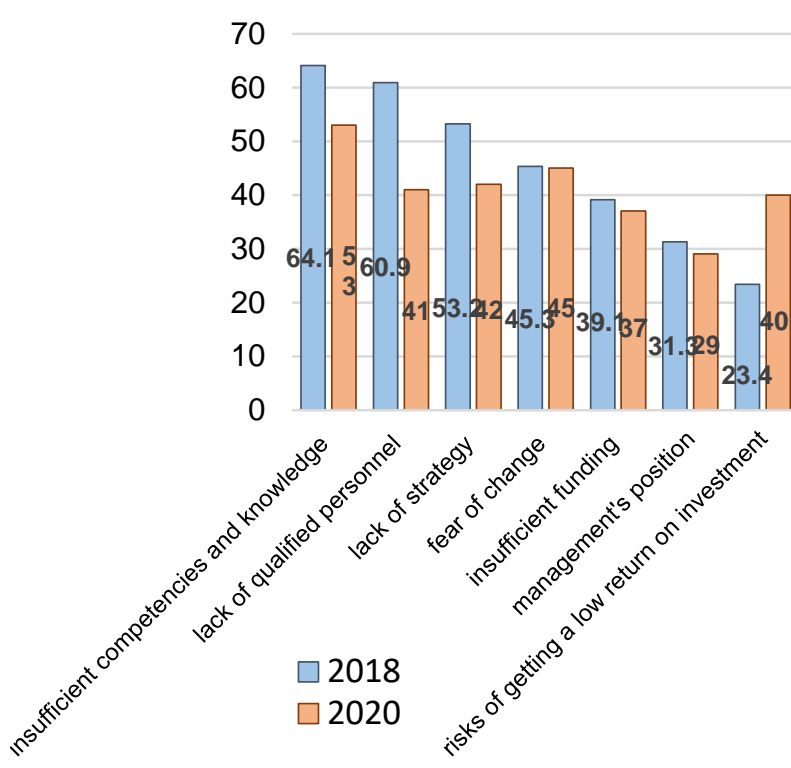

Figure 1 Key obstacles to digital transformation (according to respondents), \%.

Source: KMDA survey in 2018 [18] and 2020 [19].

The relevance of forming a culture of transformation with the involvement of all interested parties is confirmed by the results of a study by the Boston IT company SMB Group. Thus, an additional increase in profitability at the level of $18 \%$ [20] is provided by companies whose investment priority in digital transformation is the human factor, namely, social, professional and digital human competencies.

It is essential to consider the inadmissibility of mixing digital transformation goals and the entire strategic management system. Despite its exceptional importance, digital transformation is still only one of many elements of long-term development. And, consequently, such components of digital transformation as own goals, methods of achievement, methods of planning and control, required resources should be separated more clearly.

Currently, digital transformation assessment is difficult, but developing an integral indicator continues. In 2019, the Ministry of Digital Development, Communications and Mass Media undertook to develop a National Index for the Development of the Digital Economy as part of implementing the federal project "Digital Technologies" [21]. The competition was won by the Russian University of Cooperation (RUC), which is developing the index and its indicators. The projected completion date is the 4 th quarter of 2021 . The primary purpose of the indicator is to characterise the process of digitalisation of the economy in the regions.
In our opinion, the following indicators can be identified that characterise the level of digital transformation of the company:

1. Maturity of the digital transformation program (availability of a strategy, intermediate indicators, formation of a new business model);

2. Impact on consumers (improving the quality of services and reducing the response time for customer requests, increasing customer satisfaction, services become much more personalised and more consistent with individual consumption patterns, the ability to predict customer needs);

3. Digitalisation of personnel activities (remote work, equipping personnel with mobile devices, including for work control, the use of machine vision in the processes of rationing and labour organisation);

4. The share of investments aimed at the development of digital skills and competencies of personnel in the total investments of the company;

5. The index of motivation of employees involved in the processes of corporate digital transformation;

6 . The level of the digital corporate culture.

Digital transformation is a constant systemic restructuring of the business, organisational changes covering the content and processes of the company's development strategy, the result of which is the creation of an updated business model of the company that can function effectively and develop sustainably in the modern digital economy.

\section{CONCLUSIONS}

Russian state-owned companies are laying the foundation for implementing digital transformation programs for more efficient use of digital technologies, such as data-based management and customer experience management, striving for technological saturation and investing in the development of IT infrastructure and modernisation of customer service. Of course, these areas are basic for transformation and directly affect the main operating activities of the organisation, leading to rapid results.

Digital transformation involves adapting companies to natural environmental changes based on a new business philosophy that requires strategic and organisational changes. Therefore, one should not underestimate the areas that, in the long term, make an essential contribution to the innovative potential and competitiveness of the company - the creation of its new products $(R \& D)$ and the development of corporate human capital.

In the component composition of corporate human capital, which determines the level of digitalisation of 
business processes, digital competencies of employees deserve special attention as a promise for the formation and development of digital human capital and promising scientific research.

The factors that can provide a significant contribution to the digital transformation of Russian companies include a motivation system for employees involved in transformational processes and a digital corporate culture that ensures the integration of ideological, organisational and technological values, which are reflected in the list of indicators that allow us to characterise the level of digital corporate transformation.

\section{FINANCING}

This article was prepared as part of the State Task of the Ministry of Science and Higher Education of the Russian Federation on the topic "Structural shifts in the economy and society based on the results of achieving target indicators for the implementation of National projects, which provide opportunities for organising new areas of socio-economic activity, including commercial, both in Russia and abroad" (project No. FSSW-20200010).

\section{REFERENCES}

[1] The public sector in the Russian economy [Gossektor v rossijskoj ekonomike] // Bulletin on Competition [Byulleten' o konkurencii] 25 (2019) 6. Retrieved from: https://ac.gov.ru/archive/files/publication/a/21664. pdf

[2] Digital transformation of the largest business [Cifrovaya transformaciya krupnejshego biznesa] / Russian Internet portal and analytical agency "Tedweiser" [Rossijskij internet-portal i analiticheskoe agentstvo «Tedvajzer»]. Retrieved from:

https://www.tadviser.ru/index.php/Статья:Digital Transformation of the Largest Business

[3] Bharadwaj, Anandhi, A Resource-Based Perspective on Information Technology Capability and Firm Performance: An Empirical Investigation, MIS Quarterly 24. (2000) 169-196. DOI: https://doi.org/10.2307/3250983

[4] S.A. Snell \& G.W. Bohlander, Managing Human Resources. London: Cengage Learning, 2012, 832 p.

[5] I. Palmer, R. Dunford, D.A. Buchanan, Managing Organisational Change: a Multiple Perspectives Approach, 3rd Edition, International ed. New York: McGraw-Hill Education, 2017.
[6] S.A. Dyatlov, M.A. Dobrokhotov, Forms of realisation of human capital in the digital economy [Formy realizacii chelovecheskogo kapitala v cifrovoj ekonomike] // SPbSEU News [Izvestiya SPbGEU], No. 4 (112), 2018. Retrieved from: https://cyberleninka.ru/article/n/formy-realizatsiichelovecheskogo-kapitala-v-tsifrovoy-ekonomike

[7] T. Schultz, Investments in Human capital [Investicii v chelovecheskij kapital], London, 1971, 522 p.

[8] A. Lans Bovenberg, "The Life-course Perspective and Social Policies: An Overview of the Issues," CESifo Economic Studies, CESifo 54(4) (2008) 593-641.

[9] L.S. Sagdeeva, S.M. Korobko, Human capital as a factor of sustainable development in the digital economy [Chelovecheskij kapital kak faktor ustojchivogo razvitiya $\mathrm{v}$ usloviyah cifrovoj ekonomiki] // Bulletin of the Academy of Knowledge [Vestnik akademii znanij] 31(2) (2019) 211-215.

[10] Digitalisation Index 2019: Euler Hermes Report [Indeks cifrovizacii 2019: otchet Euler Hermes]. Retrieved from: https://www.eulerhermes.com/content/dam/onemar keting/ehndbx/eulerhermes_com/en_gl/erd/publicat ions/pdf/20190911TheViewEDI2019finalCOMPR ESSED.pdf

[11] The Digital Transformation Program of PJSC ROSSETI 2030 [Programma cifrovoj transformacii «PAO Rosseti» 2030] / Website of PJSC ROSSETI. Retrieved from: https://www.rosseti.ru/investment/Kontseptsiya_Ts ifrovaya transformatsiya 2030.pdf

[12] S. Stelmach, Hanover Research: Six Key Factors for Successful Digital Transformation [Hanover Research: shest' klyuchevyh faktorov uspeshnoj cifrovoj transformacii], 2020, Retrieved from: https://www.itweek.ru/digitalization/article/detail.p $\underline{\mathrm{hp}}$ ?ID=211460

[13] L.D. Saifullina, Human capital and competencies of the digital economy//Modern Economy Success 3 (2018) 58-61.

[14] V.I. Kabalina, A.V. Makarova, K.V. Reshetnikova, Motivation of employees to Learn digital skills [Reshetnikova Motivaciya rabotnikov k obucheniyu cifrovym navykam], Russian Journal of Management [Rossijskij zhurnal menedzhmenta], No. 3, 2020. Retrieved from: https://cyberleninka.ru/article/n/motivatsiyarabotnikov-k-obucheniyu-tsifrovym-navykam 
[15] T.A. Gileva, Digital maturity of the enterprise: methods of assessment and management [Cifrovaya zrelost' predpriyatiya: metody ocenki i upravleniya] // USNTU Bulletin. Science, education, economics. Series: Economics [Vestnik UGNTU, Nauka, obrazovanie, ekonomika. Seriya: Ekonomika] 1 (2019) 38-52. DOI: https://doi.org/10.17122/25418904-2019-1-27-38-52

[16] N.A. Kopylova, On the challenges of digitalisation of education, digitalisation of education: challenges of modernity: Collection of materials of the AllRussian Scientific and Methodological Conference with International participation $[\mathrm{O}$ vyzovah cifrovizacii obrazovaniya, Cifrovizaciya obrazovaniya: vyzovy sovremennosti: Sbornik materialov Vserossijskoj nauchno-metodicheskoj konferencii s mezhdunarodnym uchastiem], 2020, pp.57-62, Cheboksary: Limited Liability Company "Publishing House "Wednesday" [Cheboksary: Obshchestvo s ogranichennoj otvetstvennost'yu «Izdatel'skij dom «Sreda»].

[17] L.P.Goncharenko, N.A. Kopylova, Transformation of spheres of socio-economic activity as a result of the implementation of the national project "education", Management in the conditions of digitalisation of socio-economic processes: Collection of scientific articles [Preobrazovanie sfer social'no-ekonomicheskoj deyatel'nosti v rezul'tate realizacii nacional'nogo proekta «obrazovanie», Upravlenie $\mathrm{v}$ usloviyah cifrovizacii social'noekonomicheskih processov: sbornik nauchnyh statej], 2020, pp. 117-123, Cheboksary: Chuvash State Pedagogical University named after I.Ya. Yakovleva, Cheboksary [Cheboksary: Chuvashskij gosudarstvennyj pedagogicheskij universitet im. I.Ya. Yakovleva, Cheboksary].

[18] Digital Transformation in Russia 2020: Overview and recipes for Success: an analytical report based on the results of a survey of Russian companies [Cifrovaya transformaciya v Rossii 2020: Obzor i recepty uspekha: analiticheskij otchet na osnove rezul'tatov oprosa rossijskih kompanij]. Retrieved from: https://komanda-a.pro/projects/dtr 2020

[19] Digital Transformation in Russia 2018: Overview and recipes for Success: an analytical report based on the results of a survey of Russian companies [Cifrovaya transformaciya v Rossii 2018: Obzor i recepty uspekha: analiticheskij otchet na osnove rezul'tatov oprosa rossijskih kompanij]. Retrieved from: https://komanda-a.pro/projects/dtr 2018

[20] B.V. Martynov, E.S. Prokopenko, Management of socio-economic security in the conditions of digital transformation of society, A step into the future: artificial intelligence and digital economy: Smart Nations: the economy of digital equality: materials of the III International Scientific Forum [Prokopenko Upravlenie social'no-ekonomicheskoj bezopasnost'yu v usloviyah cifrovoj transformacii obshchestva, SHag v budushchee: iskusstvennyj intellekt i cifrovaya ekonomika: Smart Nations: ekonomika cifrovogo ravenstva: materialy III Mezhdunarodnogo nauchnogo foruma], Moscow: GUU 3 (2020) 87-92,

[21] The Digital Economy Development Index will appear at the end of 2021 [Indeks razvitiya cifrovoj ekonomiki poyavitsya v konce 2021 g.]. Retrieved from:

https://www.comnews.ru/content/211061/2020-1019/2020-w43/indeks-razvitiya-cifrovoyekonomiki-poyavitsya-konce-2021-g 